\title{
HIPNOTIZŐRÖK ARCHAIKUS BEVONÓDÁSÁNAK VIZSGÁLATA
}

\author{
BÁNYAI ÉVA ${ }^{1}$ - JÓZSA EMESE ${ }^{1}$ - KÖLTŐ ANDRÁS ${ }^{1,2}$ \\ ${ }^{1}$ ELTE Eötvös Loránd Tudományegyetem Pszichológiai Intézet \\ ${ }^{2}$ National University of Ireland Galway, Health Promotion Research Centre \\ E-mail: banyai.eva@ppk.elte.hu
}

Beérkezett: 2018. október 20. - Elfogadva: 2018. december 6.

Háttér és célkitûzések: Az alany hipnotizốrrel kapcsolatos áttételi érzelmi bevonódását az Archaikus Bevonódási Skálával - ABS(A) lehet vizsgálni. A hipnózis interaktív megközelitése azonban szükségessé teszi, hogy a hipnotizốr archaikus bevonódását is mérni lehessen. A jelen kutatásban az erre a célra általunk kialakitott huszonkét tételes hipnotizốri Archaikus Bevonódási Skála - ABS $(H)$ - megbízhatóságát, faktorszerkezetét és a bevonódás intenzitását vizsgáltuk.

Módszer: 22 hipnotizôr összesen 387 alannyal elvégzett kisérleti hipnózisa után az alanyok és hipnotizốreik egyaránt kitöltötték az ABS-t. Az alanyokra és hipnotizörökre vonatkozó adatok leíró statisztikai elemzése mellett feltáró faktoranalizissel vizsgáltuk az $A B S(H)$ kérdốv szerkezetét. Összevetettük a hipnotizôrök és alanyaik archaikus bevonódásának mértékét, illetve az egyes hipnotizörök közötti különbségeket.

Eredmények: Az $A B S(H)$ három faktorba szervezôdik: Kötôdés és pozitív kapcsolat, Gondoskodás és törödésigény, Kontrolligény és félelem a negatív megitéléstôl. $A z A B S(H)$ ugyanolyan jó megbizhatóságú, mint az $A B S(A)$. Az alanyok és hipnotizörök archaikus bevonódása között nem vagy csak alacsony hatásméretü különbséget találtunk. Az egyes hipnotizörök archaikus bevonódása viszont szignifikáns különbségeket mutatott. Következtetések: Az ABS(H) alkalmas arra, hogy laboratóriumi helyzetben megbízhatóan mérje a hipnotizôrök alannyal kapcsolatos viszontáttételi érzelmeit. Eredményeink arra utalnak, hogy az alanyok hasonló erösségú archaikus bevonódást élnek át különbözö hipnotizôrökkel, az egyes hipnotizôrök érzelmi viszonyulása azonban jelentôsen eltérhet más-más alannyal végzett laboratóriumi hipnózisok során. Ez a megfigyelés fontos adalékokat szolgáltat a hipnoterápiás kapcsolat jobb megértéséhez is.

Kulcsszavak: hipnózis, archaikus bevonódás, áttétel, viszontáttétel, interakciós szemlélet 


\section{BEVEZETÉS}

A speciális hipnotikus kapcsolat - raport - és az archaikus bevonódás fogalom kialakulásának történetét Bányai, Varga és Gôsiné Greguss (2001) részletesen tárgyalja, ezért itt csak a legfontosabb tényezóket emeljük ki.

\section{Raport}

A hipnózist alkalmazó gyógyítók - akkori elnevezéssel: „magnetizórök” - már a 18. században beszámoltak arról, hogy a magnetizmus során a magnetizốr és páciense között speciális kapcsolat, ún. raport alakul ki, ami találkozásaik között is fennmarad (Ellenberger, 1970). Franz Anton Mesmer, a modern hipnózis megalapozója a korabeli fizikából kölcsönözte a raport fogalmát, azt a mágneses „fluidum” magnetizôr és alany közötti áramlására alkalmazta. Mesmer tanítványa, Puységur márki a raportot már egyértelmúen pszichológiai természetûnek tartotta.

A raport fogalom Braid (a hipnózis szakkifejezés megalkotója) munkásságának hatására háttérbe szorult: ô inkább az alany szerepét hangsúlyozta. Hatására késôbbi fontos hipnózisszakemberek, mint például Charcot és Bernheim sem elemezték a hipnotizôr és alanya közötti raportot, bár Bernheim (1884) egy írásában a szüló-gyerek kapcsolathoz hasonlította a hipnózist. Janet (1897) hangsúlyozta, hogy a raport emocionális színezete betegrôl betegre változik, és az erotikus szenvedélytôl az anyai vagy gyermeki szeretetig sok elem keveredhet benne, de mindig van egy közös alapeleme: a páciens függôség iránti igénye. A raport fogalmáról részletes elemzés olvasható Józsa (2011) tanulmányában.

\section{Áttétel és viszontáttétel}

Pályája kezdetén Freud is alkalmazta a hipnózist (Bachner-Melman és Lichtenberg, 2001). A páciens által átélt, a terapeutára irányuló áttétel (a korábbiakban indulatáttétel) fogalmát a raportból vezette le, és ebben kereste a hipnotikus szuggesztió megértésének kulcsát. Késôbb azonban kiterjesztette a fogalom jelentését, és részletesen elemezte az áttételnek a terápiában és más kapcsolatokban betöltött szerepét.

Az áttétel folyamatának lényege Freud szerint az, hogy a páciens a múltjában gyökerezô érzelmi mozzanatokat és fantáziákat jelenít meg és vetít ki a terapeutára. Ezek az érzelmek eredetileg valamely jelentôs személyhez - leggyakrabban a páciens szüleihez - kapcsolódtak, és a terápia során elkerülhetetlenül aktiválódnak, illetve tudatosulnak; ám ezúttal a terapeutára irányulnak. Úgy vélte, hogy hipnózisban a személy infantilis regresszióba kerül, s ekkor a hipnotizôr, illetve a terapeuta szülői magatartásformát testesít meg, ami lehetôséget ad az anyához vagy apához kapcsolódó elfojtott, libidinális impulzusok, transzformált komplexusokra történô reagálásra (Freud, 1921/1995). Ferenczi (1909/2002) az áttétel jellege szerint két hipnózistípust különített el, a szeretetre épülő „anyai” és a félelmen alapuló „apai” típust. 
Noha Freud késóbb elhagyta a hipnózist, a késóbbiekben a pszichoanalitikus megközelítésû terapeuták némelyike ismét elkezdte alkalmazni azt, és a hipnózis során megjelenô áttétel különbözô formáit azonosították (Brown és Fromm, 1986; Eisen, 1993; valamint lásd Bányai tanulmányát a jelen tematikus számban pp. 7-26.).

Már maga Freud is megfigyelte - nyomában pedig Ferenczi részletesen leírta -, hogy az áttétel kölcsönös folyamat, s a terapeutában is megjelenhetnek a pácienssel szembeni viszontáttételi érzések (Cabré, 1999). Freud a viszontáttételt károsnak és a pszichoanalízis elveivel összeegyeztethetetlennek tartotta. Ez a felfogás azóta fokozatosan megváltozott, s a terapeuta viszontáttételi érzelmeinek Kernberg (1965) már diagnosztikus értéket tulajdonít, azok elemzését a pszichoanalitikus terápia egyik legfontosabb eszközének tartja.

A hipnózis erôs hatást gyakorol nemcsak az alanyra, de a hipnotizórre is. Még a látszólag semleges laboratóriumi hipnózisokban is erôs érzelmek jelenhetnek meg mindkét résztvevônél: az archaikus bevonódás kölcsönös, interaktív jelenség (Bányai, 2008; Bányai, Gôsi-Greguss, Vágó, Varga és Horváth, 1990; Bányai és Tauszik, 2009). Emiatt fontosnak tartjuk, hogy a hipnotizôr áttételi érzelmeit is az interakciós vizsgálatok tárgyává tegyük.

\section{Archaikus bevonódás}

A hipnózis 20. századi reneszánszát elôsegítő kutatók közül Shor $(1962,1979)$ volt az elsô, aki - a pszichoanalitikus szerzókkel egyetértésben - a hipnózis egyik alapvetô dimenziójának tekintette a hipnotizőr és hipnotizált kapcsolatát. Shor szerint a hipnózis lényege csak akkor tárul fel, ha két ember közötti dinamikus kölcsönhatásként fogjuk azt fel. White (1941) kétdimenziós hipnózismodelljét kiegészítve - ahol a hipnotikus szerepjátszás és a transz dimenziók képezték a megközelítés két alappillérét - Shor a kapcsolatot tekinti a hipnózis harmadik pillérének. Ennek a dimenziónak az archaikus bevonódás nevet adta. Az archaikus bevonódás alapjának a hipnotizốr személyére irányuló (archaikus) tárgykapcsolatot tekinti. Bár szerinte az archaikus bevonódás kísérleti körülmények között nem, csak a terápiás helyzetben alakul ki, az 1970-es évektôl kezdve több kutatócsoport - pl. Sheehan és Dolby (1979), illetve Levitt, Baker és Fish (1990) - is empirikus vizsgálatokat kezdett e jelenség megértésére.

Az alanyok archaikus bevonódásának gyors és megbízható mérésére Nash és Spinler (1989) dolgozott ki papír-ceruza tesztet. A 452 vizsgálati személy részvételével elvégzett validálási vizsgálatok alapján tizenkilenc tételes Archaikus Bevonódási Skálát (ABS) alakítottak ki. Elemzésük szerint az ABS megbízható (Cronbach-alfa: 0,95), és a skálán belül három faktor különíthetô el: 1. A hipnotizôr hatalmának érzékelése (tételei: 3, 4, 9, 12, 13 és 14), 2. A hipnotizôrhöz való pozitív érzelmi kötôdés (tételei: 1, 2, 5, 6, 7, 8 és 11) és 3. A negatív megitéléstôl való félelem (tételei: 10, 15, 16, 17, 18 és 19). A faktorok által megmagyarázott variancia rendre 23,32\%, 22,59\% és 22,27\%, összesen $68,18 \%$.

Munkacsoportunk magyar mintán is elvégezte az ABS faktorszerkezetének elemzését (Bányai, Varga és Gôsiné Greguss, 2001). Az 593 alany hipnózis után kitöltött kérdőíveinek faktoranalízise szintén három, az eredeti változattól kissé eltérô faktort 
azonosított: 1. Csodálat és kötôdés (tételei: 1, 3, 4, 5, 6, 7, 8, 9 és 11); 2. Félelem a negatív megitéléstôl (tételei: 2., 10., 16., 17., 18., és 19) és 3. Függốségigény (tételei: 12, 13, 14 és 15). A három faktor által megmagyarázott variancia rendre 27,61\%, 19,94\%, illetve $14,16 \%$, összesen $61,71 \%$. A tizenkilenc tétel összesítve a (pozitív) archaikus bevonódás indikátora (ABS+); a három faktor pedig az egyes dimenziók mérésére alkalmas.

\section{Az archaikus bevonódás tágabb értelmezése}

Az interakciós szemléletnek és a hipnózis szociál-pszichobiológiai elméletének megfelelốen (lásd Bányai tanulmányát a jelen tematikus számban, pp. 7-26.) az archaikus bevonódás kérdôíves vizsgálatát két szempont alapján kiterjesztettük. A hipnózis interakciók utáni Párhuzamos Élményelemzô Technikával feltárt élmények arra utaltak, hogy az áttételi kapcsolat negatív érzelmi színezetú is lehet, illetve a hipnotizôröknél is megjelenik (Bányai és mtsai, 1990; Varga, 2017; Varga, Bányai és Gôsi-Greguss, 1994). Mivel az eredeti skála a bevonódásnak csak a pozitív oldalát vizsgálja, kidolgoztuk az archaikus bevonódás negatív vetületének mérôeszközét (ABS-), illetve az ABS(H) kérdőívet a hipnotizórök archaikus bevonódásának mérésére.

A negatív bevonódást mérô változat az eredeti tizenkilenc pozitív tétel tartalmi ellentétpárjaiból állt (pl. az eredeti kérdőív 9. tétele: „Valahogy jólesett részesülni a hipnotizôr hatalmában”, aminek negatív bevonódásra utaló átfogalmazása: „Valahogy rosszul esett, hogy szinte eltörpültem a hipnotizôr mellett”). A vizsgálati személyek jelentôs része nem vagy csak alig számolt be ilyen negatív érzelmekrôl, azaz padlóhatás érvényesült. Emiatt végül az ABS-nek egy olyan huszonkét tételes változatát alakítottuk ki, melyben az eredeti tizenkilenc pozitív bevonódásra utaló tételt a skála végén három negatív tétel egészíti ki (az a három tétel, amely a negatív skála kidolgozásakor elvégzett vizsgálatban a legmagasabb átlagértékeket kapta). Ezt a változatot (1. melléklet) használtuk azokban a hipnóziskísérletekben is, melyeket a jelen tanulmány bemutat. A huszonkét tételes változatból alanyok esetén tehát számolható egy ABS+ összpontszám, aminek értéke a pozitív bevonódás mértékével egyenesen arányos (a tizenkilenc pozitív tétel alapján, az elérhetô pontszám 19-133 pont között változhat), egy ABS- összpontszám, amely a negatív bevonódás mértékét tükrözi (a három negatív tétel alapján, tehát 3-21 pont közötti értéket vehet fel), illetve a három pozitív faktor átlagolt pontszáma (Csodálat és kötôdés; Félelem a negatív megitéléstôl és Függôségigény, értékük 1-7 pont között lehet), melyek a pozitív bevonódás finomabb elemzését teszik lehetôvé.

$\mathrm{Az} \operatorname{ABS}(\mathrm{H})$ az alanyok kérdőívében alkalmazott huszonkét tétel hipnotizôr nézôpontjából értelemszerúen átfogalmazott változatából áll (pl. a kérdőív 9. tétele: „Valahogy jólesett részesülni a hipnotizốr hatalmában” helyett: „Valahogy jólesett az alanyt a hatalmamban részesíteni" (2. melléklet).

A jelen elemzés célja, hogy megvizsgáljuk a hipnotizôrök esetében is az ABS kérdőív megbízhatóságát és faktorszerkezetét, illetve összehasonlítsuk az alanyok és hipnotizôrök archaikus bevonódását egyéni hipnóziskísérletek során. Vizsgálatunkkal azt a hipotézist is tesztelni kívántuk, hogy a hipnotizôrök az alanyokéhoz hasonló erôsségú tárgykapcsolati érzelmeket élnek át hipnózis során. 


\section{MÓDSZER}

\section{Az elemzett egyéni hipnóziskisérletek rövid áttekintése}

A jelen tanulmány az ELTE PPK Affektív Pszichológia Tanszékén múködô Hipnóziskutató Laboratórium négy korábbi vizsgálata keretében végzett egyéni hipnózisok ABS-adatainak másodlagos elemzésén alapul.

Kutatócsoportunk az önként jelentkezô alanyoktól és kísérleteinkben önkéntesen dolgozó hipnotizőröktôl minden esetben informált, írott beleegyezést kért. Az ELTE PPK Kutatásetikai Bizottság 2015/271. számú határozatában engedélyezte, hogy kutatócsoportunk az ABS-t és más mérôeszközöket standard laboratóriumi hipnózisok keretében használja.

Két kísérletben a hipnábilitás mérésére standard eljárást, a Stanford Hipnotikus Szuszceptibilitási Skála A és C változatának (Weitzenhoffer és Hilgard, 1959, 1962) magyarra adaptált formáját (SHSS:A: Mészáros, Bányai, Greguss, Gerber és Csókay, 1973), illetve SHSS:C: Bányai, Mészáros, Greguss, Gerber és Csókay, 1974) alkalmaztuk. Egy további kísérlet részben volt standard: az SHSS:C protokollját egészítették ki egyéb feladatok. Feldolgoztuk egy szabad interakciót alkalmazó hipnózissorozat adatait is: a hipnotizốrök szabad raportalakítás, indukció és mélyítés után szintén szabadon alakítottak ki analgéziát az alanyok szubdomináns kezére, amit három előre meghatározott, standard feladat és szabad dehipnózis követett. A kísérletsorozatok további részleteit lásd Józsa (2012); Varga (2017).

\section{Résztvevók}

A négy vizsgálatban összesen 387 alany ( 147 férfi és 248 nó, átlagéletkoruk 33,78ะ14,43 év, 15 és 79 év közöttiek) és 22 hipnotizôr ( 4 férfi, 18 nô; átlagéletkor 40 év, 24 és 63 év közöttiek) vett részt. A hipnotizốrök által végzett hipnózisok száma jelentôsen eltért: volt olyan hipnotizôr, aki csak egy alkalommal hipnotizált, míg az egy hipnotizốr által vezetett legtöbb alkalom nyolcvan volt. Az ABS kérdôív alapján végzett elemzésből adathiány miatt két ülés adatait töröltük.

\section{Statisztikai elemzés}

Az $\operatorname{ABS}(\mathrm{H})$ szerkezetének vizsgálatára a pozitív tételeken feltáró faktorelemzést végeztünk. Ellenôriztük a kapott faktorok és a pozitív-negatív skálák reliabilitását. A hipnotizőrök és alanyok ABS-pontszámait Mann-Whitney-próbával, az egyes hipnotizōrök és alanyaik archaikus bevonódását (a hipnotizốr személye szerint) egyszempontos varianciaanalízissel vizsgáltuk. Mivel a szóráshomogenitás feltétele sérült, és az egyes hipnotizôrök jelentôsen eltérô számú hipnózist végeztek, a varianciaanalízis során bootstrap technikát alkalmaztunk (az iterációk száma: 1000). 


\section{EREDMÉNYEK}

\section{A hipnotizör ABS faktoranalizise}

Az egyes hipnotizôrök által végzett hipnózisok száma erôsen szóródott (1-80 egyéni hipnózis), ezért az ABS+ tizenkilenc tételét felhasználva a faktoranalízist két módon is elvégeztük. 1. A teljes mintán (387 hipnózisülés három kísérletből) és 2. az egyik vizsgálat standard, SHSS:A üléseiból kiválasztva azoknak a hipnotizóröknek az üléseit, akik legalább 12 ülést vezettek (akik többet, azoknál az elsô 12 ülést); így tíz hipnotizôrtôl összesen 120 ülést elemeztünk. Ezt az indokolta, hogy az ülések nem teljesen tekinthetôk függetlennek egymástól, hiszen a hipnotizórök általában több alkalommal is hipnotizáltak, 32 alany pedig kétfordulós vizsgálat során kétszer is részt vett hipnózison. Ez az elsôfajú hiba megemelkedését eredményezi (design effect, DEFF). A hipnotizőrök többszöri szereplése az ilyen vizsgálatokban nem küszöbölhetô ki, azonban az egyes hipnotizôrôk által vezetett ülések számának nagy változatossága magas DEFF-értékeket eredményezett, illetve az összminta esetén a kísérleti elrendezés sem volt egységes. A második faktoranalízis biztosította, hogy azonos kísérleti helyzetben azonos mennyiségú ülést vezetô hipnotizőrök üléseit elemezhessük, alacsonyabb DEFF-értékek mellett. Mivel a két elemzés azonos faktorszerkezetet eredményezett (1. táblázat), a továbbiakban a nagyobb mintán, több hipnotizôr adatával végzett elemzés eredményeit mutatjuk be.

A Kaiser-Meyer-Olkin-mutató (a teljes mintában $\mathrm{KMO}=0,919$ ) és a Bartlett-teszt $(p<0,001)$ megerôsítette, hogy az $\mathrm{ABS}(\mathrm{H})$ tételei alávethetôk a feltáró faktoranalízisnek. A Varimax rotációval elvégzett fơkomponens-elemzés (1. táblázat) három faktort eredményezett, melyek jól illeszkednek az ABS(A) eredeti, illetve magyar mintán talált, fentebb ismertetett faktoraihoz. A teljes, 387 fős mintában a megbízhatósági mutatók a következôk: 1. Kötôdés és pozitív kapcsolat (Cronbach-alfa =0,88); 2. Gondoskodás és törôdésigény (Cronbach-alfa $=0,90)$, 3. Kontrolligény és félelem a negatív megitéléstôl (Cronbach-alfa = 0,92). A három faktor által megmagyarázott variancia rendre $28,54 \%, 21,24 \%$, illetve $19,73 \%$, összesen $69,51 \%$.

1. táblázat. Az $\mathrm{ABS}+(\mathrm{H})$ feltáró faktoranalízisének eredménye a feldolgozott 387 egyéni hipnózisülés, illetve a részleges, 120 hipnózisülésból álló minta alapján

(fớkomponens-elemzés, Varimax rotációval)

\begin{tabular}{|c|c|c|c|c|c|c|}
\hline & \multicolumn{3}{|c|}{$\begin{array}{l}\text { Teljes minta } \\
(N=387)\end{array}$} & \multicolumn{3}{|c|}{$\begin{array}{l}\text { Részleges minta } \\
\qquad(N=120)\end{array}$} \\
\hline & F1 & F2 & F3 & F1 & F2 & F3 \\
\hline & \multicolumn{6}{|c|}{ Kötôdés és pozitív kapcsolat } \\
\hline $\begin{array}{l}\text { 1. Néha úgy éreztem, hogy nagyon erósen } \\
\text { kötốdöm a hipnotizálthoz. Olyan érzés volt ez, } \\
\text { amit általában csak a gyerekei, egyes betegei/ } \\
\text { tanítványai és a legjobb barátai iránt érez az } \\
\text { ember. }\end{array}$ & 0,85 & 0,21 & 0,10 & 0,80 & 0,30 & 0,17 \\
\hline $\begin{array}{l}\text { 2. Nem is tudom miért, de valahogy tényleg } \\
\text { nagyon a hipnotizált kedvében akartam járni. }\end{array}$ & 0,79 & 0,14 & 0,33 & 0,85 & 0,10 & 0,27 \\
\hline $\begin{array}{l}\text { 3. Úgy tûnt, hogy a hipnotizált minden szava és } \\
\text { tette valahogy befolvásolta az érzéseimet. }\end{array}$ & 0,67 & 0,24 & 0,41 & 0,66 & 0,25 & 0,39 \\
\hline
\end{tabular}




\begin{tabular}{|c|c|c|c|c|c|c|}
\hline & \multicolumn{3}{|c|}{$\begin{array}{c}\text { Teljes minta } \\
(N=387)\end{array}$} & \multicolumn{3}{|c|}{$\begin{array}{l}\text { Részleges minta } \\
\quad(N=120)\end{array}$} \\
\hline & $\mathrm{F} 1$ & F2 & F3 & $\mathrm{F} 1$ & $\mathrm{~F} 2$ & F3 \\
\hline $\begin{array}{l}\text { 4. Úgy éreztem, hogy minden, amit a hipnotizált } \\
\text { tett és mondott, mélyen érint. }\end{array}$ & 0,64 & 0,34 & 0,41 & 0,76 & 0,27 & 0,32 \\
\hline \multirow[t]{2}{*}{$\begin{array}{l}\text { 8. Rendkívüli csodálatot éreztem a hipnotizált } \\
\text { iránt. }\end{array}$} & 0,71 & 0,23 & 0,12 & 0,65 & 0,33 & 0,19 \\
\hline & \multicolumn{6}{|c|}{ Gondoskodás és törôdésigény } \\
\hline $\begin{array}{l}\text { 5. Amíg hipnotizáltam, szinte esendónek } \\
\text { éreztem a hipnotizáltat. }\end{array}$ & 0,27 & 0,85 & 0,15 & 0,26 & 0,88 & 0,16 \\
\hline $\begin{array}{l}\text { 6. Úgy éreztem, hogy a hipnotizált gyámolításra } \\
\text { szorul. }\end{array}$ & 0,21 & 0,87 & 0,18 & 0,24 & 0,88 & 0,17 \\
\hline 7. Kissé naivnak éreztem a hipnotizáltat. & 0,02 & $\mathbf{0 , 8 0}$ & 0,19 & 0,04 & $\mathbf{0 , 8 6}$ & 0,17 \\
\hline $\begin{array}{l}\text { 11. Valahogy inkább gyermekével lévố szülônek } \\
\text { éreztem magam, mintsem egy felnôttel lévố } \\
\text { hipnotizőrnek. }\end{array}$ & 0,39 & 0,73 & 0,06 & 0,41 & 0,77 & 0,15 \\
\hline $\begin{array}{l}\text { 12. Úgy éreztem, hogy én vagyok a vezetô, a } \\
\text { hipnotizált pedig követ engem. }\end{array}$ & 0,29 & 0,59 & 0,41 & 0,41 & 0,61 & 0,29 \\
\hline \multirow[t]{2}{*}{$\begin{array}{l}\text { 13. Amíg hipnotizáltam, vigyázni, óvni akartam a } \\
\text { hipnotizáltat. }\end{array}$} & 0,49 & $\mathbf{0 , 5 5}$ & 0,42 & 0,53 & $\mathbf{0 , 5 7}$ & 0,44 \\
\hline & \multicolumn{6}{|c|}{$\begin{array}{l}\text { Kontrolligény és félelem } \\
\text { a negatív megítéléstôl }\end{array}$} \\
\hline $\begin{array}{l}\text { 9. Valahogy jólesett a hipnotizáltat a } \\
\text { hatalmamban részesíteni. }\end{array}$ & 0,30 & 0,45 & $\mathbf{0 , 5 9}$ & 0,45 & 0,49 & 0,51 \\
\hline $\begin{array}{l}\text { 10. Arra törekedtem, hogy a hipnotizált meg } \\
\text { akarjon felelni nekem. }\end{array}$ & 0,09 & 0,25 & $\mathbf{0 , 8 0}$ & 0,26 & 0,25 & 0,75 \\
\hline $\begin{array}{l}\text { 14. Én akartam meghatározni, hogy a hipnotizált } \\
\text { mit tegyen. }\end{array}$ & 0,07 & 0,27 & 0,80 & 0,24 & 0,30 & 0,73 \\
\hline 15. Azt akartam, hogy a hipnotizált rám figyeljen. & 0,16 & 0,26 & 0,73 & 0,45 & 0,27 & 0,54 \\
\hline $\begin{array}{l}\text { 16. Amikor olyat kértem, amit a hipnotizált nem } \\
\text { tudott megtenni, rossz érzésem támadt. }\end{array}$ & 0,18 & 0,07 & 0,70 & 0,05 & 0,16 & 0,79 \\
\hline $\begin{array}{l}\text { 17. Aggasztott, hogy a hipnotizált nem kedvel } \\
\text { majd. }\end{array}$ & 0,22 & 0,08 & 0,79 & 0,18 & 0,11 & 0,83 \\
\hline $\begin{array}{l}\text { 18. El akartam kerülni, hogy a hipnotizált } \\
\text { csalódjon bennem. }\end{array}$ & 0,38 & 0,11 & 0,75 & 0,44 & 0,13 & 0,77 \\
\hline $\begin{array}{l}\text { 19. El akartam kerülni, hogy a hipnotizált } \\
\text { megharagudjon rám. }\end{array}$ & 0,29 & 0,09 & 0,80 & 0,35 & 0,09 & 0,51 \\
\hline Rotáció utáni variancia $(\%)$ : & 28,54 & 21,24 & 19,73 & 23,46 & 23.55 & 0,75 \\
\hline Rotáció utáni halmozott variancia (\%): & 28,54 & 49,78 & 69,51 & 23,46 & 47.01 & 0,73 \\
\hline
\end{tabular}

Megjegyzés: Az összminta (387 ülés, 22 hipnotizôr adatai) alapján a DEFF-értékek: ABS+(H) 11,53; ABS-(H) 5,15; Kötôdés és pozitív kapcsolat 8,96; Gondoskodás és törôdésigény 7,64; Kontrolligény és félelem a negatív megítéléstôl 13,54. A fentivel megegyezô faktorokat eredményezô második faktoranalízis (azonos kísérleti helyzetben azonos mennyiségú hipnózist végzô hipnotizôrök,120 hipnózis, 10 hipnotizôr) mintájában a DEFF-értékek: ABS+(H) 8,07; ABS-(H) 2,09; Kötôdés és pozitív kapcsolat 6,14; Gondoskodás és törôdésigény 9,57; Kontrolligény és félelem a negatív megítéléstôl 4,61. 


\section{Az Archaikus Bevonódási Skála megbizhatósági elemzése}

Az ABS kérdôív megbízhatósági elemzését mind az eredeti, csak a tizenkilenc pozitív tételt tartalmazó változat, mind a három negatív tétel esetén, illetve a faktorok alapján is elvégeztük, az alanyok és hipnotizőrök almintáján is. Eszerint az ABS+ megbízhatósági mutatója mindkét esetben megfelelô, míg az ABS- esetén a Cronbach-alfa nem éri el a konvencionálisan elfogadott 0,70-es értéket, bár a hipnotizőrök mintáján megközelíti azt (2. táblázat). Ezeknek a kissé alacsony értékeknek a tételek csekély száma lehet az oka.

Az ABS+ kérdőív faktoraira vonatkozóan is elvégeztük a megbízhatósági elemzést, aminek alapján a faktorok megbízhatósága mind az alanyok, mind a hipnotizôrök mintáján megfelelô (2. táblázat).

2. táblázat. Az alanyok és hipnotizôrök ABS kérdôívének Cronbach-alfa értékei

\begin{tabular}{c|c|l|c}
\hline \multicolumn{2}{c|}{ Alanyok (387 ülés) } & \multicolumn{2}{c}{ Hipnotizórök (387 ülés) } \\
\hline \multicolumn{1}{c|}{ Skála/faktor } & Cronbach-alfa & \multicolumn{1}{c}{ Skála/faktor } & Cronbach-alfa \\
\hline ABS+(A) & 0,92 & ABS+(H) & 0,94 \\
\hline ABS-(A) & 0,61 & ABS- $(\mathrm{H})$ & 0,68 \\
\hline Csodálat és kötốdés & 0,94 & $\begin{array}{l}\text { Kötôdés és pozitív } \\
\text { kapcsolat }\end{array}$ & 0,88 \\
\hline $\begin{array}{l}\text { Félelem a negatív } \\
\text { megítéléstôl }\end{array}$ & 0,87 & $\begin{array}{l}\text { Gondoskodás és } \\
\text { törôdésigény }\end{array}$ & 0,90 \\
\hline Függốségigény & 0,83 & $\begin{array}{l}\text { Kontrolligény és félelem } \\
\text { a negatív megítéléstôl }\end{array}$ & 0,92 \\
\hline
\end{tabular}

\section{A hipnotizôrök archaikus bevonódásának mértéke és egyéni különbségei}

Megvizsgáltuk, hogy a hipnotizőrök és az alanyok archaikus bevonódásának mértéke hogyan viszonyul egymáshoz. A 3. táblázat foglalja össze az alanyok és hipnotizôrök archaikus bevonódásának leíró statisztikai adatait és összehasonlításuk eredményét. Az alanyok és hipnotizôrök pontszámainak összevetése a kérdőív eltéró faktorszerkezete miatt csak az ABS+ és ABS- pontszámoknál lehetséges. Bár ahogy a táblázatról leolvasható, a Mann-Whitney-próba szerint az alanyok szignifikánsan intenzívebb pozitív archaikus bevonódásról számolnak be, mint a hipnotizôrök, a hatásméret alacsony (Cohen- $d=0,37$ ). A negatív bevonódás esetén a különbség nem szignifikáns az alanyok és hipnotizőrök között. A 22 hipnotizôr által a 387 interakció során az ABS(H)

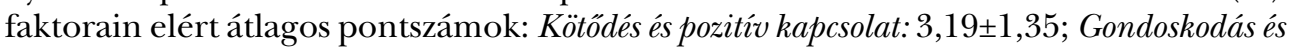

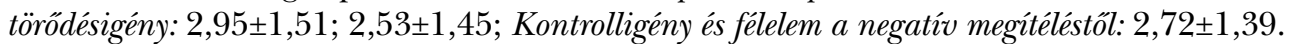

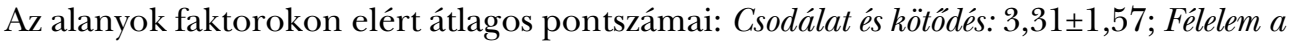

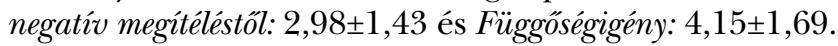

\section{A hipnotizốr személyének hatása az archaikus bevonódásra}

Egyszempontos varianciaanalízissel hasonlítottuk össze az alanyok és hipnotizőrök ABS-pontszámait a hipnotizôr személyének szempontját használva, bootstrap mód- 
3. táblázat. Az ABS kérdôív leíró adatai a hipnotizőrök mintáján, illetve az alanyok és a hipnotizôrök ABS+ és ABS- pontszámainak összehasonlítása

\begin{tabular}{|c|c|c|c|c|c|}
\hline & \multirow{2}{*}{$\begin{array}{l}\text { Az ABS(A) kérdó- } \\
\text { íven elért pontszá- } \\
\text { mok az }(n=387) \\
\text { átlag } \\
\text { szórás }\end{array}$} & \multirow{2}{*}{$\begin{array}{l}\text { Az ABS(H) kérdó- } \\
\text { íven elért }(n=387) \\
\text { átlag } \\
\text { szórás }\end{array}$} & \multicolumn{3}{|c|}{$\begin{array}{l}\text { A hipnotizórök és alanyok archaikus } \\
\text { bevonódásának összehasonlítása }\end{array}$} \\
\hline & & & Mann-Whitney- $U$ & $p$ & Cohen- $d$ \\
\hline $\mathrm{ABS}+$ & $\begin{array}{ll}64,16 & \min .: 19 \\
\pm 24,22 & \text { max.: } 133 \\
\end{array}$ & $\begin{array}{ll}55,35 & \min .: 19 \\
\pm 23,12 & \text { max.: } 124 \\
\end{array}$ & 58803 & $<0,01$ & 0,37 \\
\hline ABS- & 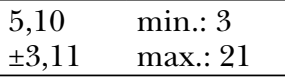 & $\begin{array}{ll}4,49 & \min .: 3 \\
\pm 2,43 & \text { max.: } 18 \\
\end{array}$ & 69644 & 0,07 & 0,22 \\
\hline
\end{tabular}

szerrel. Az alanyok ABS+(A) és ABS-(A) pontszámai között az ANOVA nem mutatott ki szignifikáns különbséget a hipnotizôr személyének foohatása alapján: $\mathrm{ABS}(+)$ : $F(386)=1,30 ; p=0,17$ ns.; ABS(-): $F(386)=0,79 ; p=0,73$ ns. A faktorok közül a Félelem a negatív megitéléstôl és a Függôségigény esetében szintén nem találtunk szignifikáns különbséget: $\mathrm{ABS}(\mathrm{A})$ Félelem a negatív megitéléstôl $F(386)=1,02 ; p=0,44$ ns.; ABS(A) Függốségigény $F(386)=1,04 ; p=0,41$ ns. Jelentôsnek tûnô különbség mindössze a Csodálat és kötôdés faktor esetében mutatkozott: $\mathrm{ABS}(\mathrm{A})$ Csodálat és kötődés $F(386)$ = 1,72; $p=0,03$, azonban a Scheffé-módszerrel végzett post hoc páros összehasonlítások itt sem mutattak ki szignifikanciát a hipnotizôrök iránti archaikus bevonódás mértékében. Ezért ebben a bontásban az alanyok pontszámait nem közöljük.

A hipnotizőrök között minden $\mathrm{ABS}(\mathrm{H})$ mutató esetében találtunk szignifikáns különbséget mind a hipnotizôr fơhatása, mind a post hoc páros összehasonlítások alapján. A hipnotizôrök pontszámainak leíró statisztikai adatait az 4. táblázat tartalmazza. A hipnotizôrök ABS-pontszámainak összehasonlítása a hipnotizôr személyének foohatása szerint a következó: ABS+(H): $F(386)=38,13 ; p<0,001 ; \mathrm{ABS}-(\mathrm{H}): F(386)=5,70$; $p<0,001$; ABS $(\mathrm{H})$ Kötódés és pozitív kapcsolat: $F(386)=16,89 ; p<0,001 ; \mathrm{ABS}(\mathrm{H})$ Gondoskodás és törôdésigény: $F(386)=13,21 ; p<0,001 ; \mathrm{ABS}(\mathrm{H})$ Kontrolligény és félelem a negatív megítéléstól: $F(386)=70,34 ; p<0,001$.

\section{Összefüggések az archaikus bevonódás és az alany hipnotikus válaszkészsége között}

Jelen vizsgálatunk megerôsítette Nash és Spinler (1989) megfigyeléseit, valamint saját korábbi eredményeinket (Bányai és mtsai, 1990), miszerint az alanyok aktuális hipnotikus válaszkészsége és pozitív archaikus bevonódása között szignifikáns pozitív kapcsolat van $(r=0,41 ; \mathrm{p}<0,001)$. A hipnotizôrök pozitív archaikus bevonódása is szignifikánsan, pozitívan függött össze alanyaik szuggesztiókra adott válaszainak számával $(r=0,27 ; \mathrm{p}<0,001)$. Míg az alanyoknál az ABS+ faktorai külön-külön nem függtek össze hipnotikus válaszaikkal, a hipnotizóröknél az alanyok magasabb hipnotikus válaszkészsége különösen a Gondoskodás és törôdésigény faktor magasabb pontszámával $(r=0,41 ; \mathrm{p}<0,001)$ és a Kötôdés és pozitív kapcsolat mértékével $(r=0,26$; $\mathrm{p}<0,001)$ járt együtt. 
4. táblázat. Leíró statisztikai adatok: A hipnotizőrök ABS-pontszámainak átlaga és szórása

\begin{tabular}{|c|c|c|c|c|c|}
\hline Hipnotizőr & $\mathrm{ABS}+(\mathrm{H})$ & ABS- $(\mathrm{H})$ & $\begin{array}{l}\text { Kötôdés } \\
\text { és pozitív } \\
\text { kapcsolat }\end{array}$ & $\begin{array}{c}\text { Gondoskodás } \\
\text { és törốdés- } \\
\text { igény }\end{array}$ & $\begin{array}{l}\text { Kontrolligény } \\
\text { és félelem a } \\
\text { negatív meg- } \\
\text { ítéléstôl }\end{array}$ \\
\hline $\begin{array}{l}\text { 1. (38 ülés) } \\
37 \text { éves nố }\end{array}$ & $\mathbf{4 1 , 9 8} \pm 11,39$ & $\mathbf{3 , 7 1} \pm 1,62$ & $\mathbf{2 , 4 2} \pm 0,77$ & $\mathbf{2 , 5 5} \pm 1,19$ & $\mathbf{1 , 8 2} \pm 0,50$ \\
\hline $\begin{array}{l}\text { 2. (10 ülés) } \\
59 \text { éves férfi }\end{array}$ & $\mathbf{5 9 , 3 0} \pm 14,92$ & $\mathbf{5 , 3 0 \pm 3 , 4 6}$ & $\mathbf{2 , 4 5} \pm 0,95$ & $\mathbf{2 , 7 5} \pm 0,90$ & $\mathbf{3 , 8 8} \pm 0,73$ \\
\hline $\begin{array}{l}\text { 3. (19 ülés) } \\
36 \text { éves nố }\end{array}$ & $\mathbf{3 8 , 7 9} \pm 8,62$ & $\mathbf{3 , 2 1} \pm 0,71$ & $\mathbf{2 , 4 2} \pm 0,45$ & $\mathbf{1 , 8 6} \pm 0,74$ & $\mathbf{1 , 9 4} \pm 0,44$ \\
\hline $\begin{array}{l}\text { 4. (18 ülés) } \\
62 \text { éves nố }\end{array}$ & $\mathbf{6 7 , 2 8} \pm 23,23$ & $4,17 \pm 2,45$ & $\mathbf{3 , 1 3} \pm 1,04$ & $4,07 \pm 2,05$ & $\mathbf{3 , 3 9} \pm 1,15$ \\
\hline $\begin{array}{l}\text { 5. (6 ülés) } \\
40 \text { éves nố }\end{array}$ & $\mathbf{6 3 , 0 0} \pm 13,37$ & $\mathbf{4 , 6 7} \pm 2,66$ & $\mathbf{3 , 7 0} \pm 0,73$ & $\mathbf{3 , 7 2} \pm 1,59$ & $\mathbf{2 , 7 7 \pm 0 , 7 5}$ \\
\hline $\begin{array}{l}\text { 6. (8 ülés) } \\
44 \text { éves férfi }\end{array}$ & $\mathbf{5 8 , 2 5} \pm 12,60$ & $\mathbf{4 , 2 5} \pm 1,91$ & $\mathbf{3 , 7 2} \pm 0,68$ & $\mathbf{2 , 9 4} \pm 0,83$ & $\mathbf{2 , 7 5} \pm 0,76$ \\
\hline $\begin{array}{l}\text { 7. (9 ülés) } \\
51 \text { éves nô } \\
\end{array}$ & $40,11 \pm 5,35$ & $\mathbf{3 , 0 0} \pm 0,00$ & $\mathbf{1 , 7 1} \pm 0,49$ & $\mathbf{2 , 0 2} \pm 0,50$ & $\mathbf{2 , 4 3} \pm 0,76$ \\
\hline $\begin{array}{l}\text { 8. (4 ülés) } \\
35 \text { éves nô }\end{array}$ & $41,75 \pm 12,71$ & $\mathbf{3 , 0 0} \pm 0,00$ & $\mathbf{2 , 1 6} \pm 0,68$ & $\mathbf{2 , 7 5} \pm 1,40$ & $\mathbf{1 , 8 1} \pm 0,16$ \\
\hline $\begin{array}{l}\text { 9. (80 ülés) } \\
52 \text { éves nố }\end{array}$ & $\mathbf{3 5 , 8 0} \pm 11,85$ & $\mathbf{3 , 9 2} \pm 1,84$ & $\mathbf{2 , 5 3} \pm 1,21$ & $\mathbf{1 , 9 3} \pm 0,97$ & $\mathbf{1 , 4 4} \pm 0,47$ \\
\hline $\begin{array}{l}\text { 10. (6 ülés) } \\
35 \text { éves nố }\end{array}$ & $\mathbf{8 1 , 0 0 \pm 1 4 , 2 1}$ & $\mathbf{9 , 3 3} \pm 5,35$ & $\mathbf{3 , 8 0} \pm 0,83$ & $\mathbf{4 , 1 9 \pm 1 , 4 5}$ & $\mathbf{4 , 6 0} \pm 0,78$ \\
\hline $\begin{array}{l}\text { 11. (10 ülés) } \\
47 \text { éves férfi }\end{array}$ & $\mathbf{1 9 , 2 0} \pm 0,42$ & $\mathbf{3 , 0 0} \pm 0,00$ & $\mathbf{1 , 0 0} \pm 0,00$ & $\mathbf{1 , 0 3} \pm 0,07$ & $\mathbf{1 , 0 0} \pm 0,00$ \\
\hline $\begin{array}{l}12 . \text { ( } 6 \text { ülés) } \\
44 \text { éves nô } \\
\end{array}$ & $\mathbf{6 3 , 1 7} \pm 9,35$ & $\mathbf{5 , 3 3} \pm 2,25$ & $\mathbf{3 , 8 0} \pm 1,06$ & $\mathbf{2 , 8 0} \pm 1,30$ & $\mathbf{3}, \mathbf{4 2} \pm 0,23$ \\
\hline $\begin{array}{l}\text { 13. (23 ülés) } \\
30 \text { éves nô }\end{array}$ & $\mathbf{7 5 , 4 3} \pm 13,43$ & $\mathbf{5 , 6 5} \pm 1,85$ & $\mathbf{3 , 7 3} \pm 0,90$ & $\mathbf{3 , 0 0} \pm 1,06$ & $\mathbf{4 , 8 5} \pm 0,76$ \\
\hline $\begin{array}{l}\text { 14. (10 ülés) } \\
38 \text { éves nô }\end{array}$ & $\mathbf{5 9 , 5 0} \pm 19,69$ & $\mathbf{5 , 3 0} \pm 1,63$ & $3,22 \pm 1,01$ & $\mathbf{3 , 1 8} \pm 1,54$ & $\mathbf{3 , 0 4} \pm 0,87$ \\
\hline $\begin{array}{l}15 . \text { (45 ülés) } \\
35 \text { éves férfi }\end{array}$ & $\mathbf{6 0 , 4 2} \pm 13,67$ & $\mathbf{5 , 4 9} \pm 2,31$ & $\mathbf{3 , 6 3} \pm 1,00$ & $\mathbf{3 , 2 6} \pm 1,18$ & $\mathbf{2 , 8 4} \pm 0,66$ \\
\hline $\begin{array}{l}\text { 16. (23 ülés) } \\
27 \text { éves nố }\end{array}$ & $\mathbf{9 8 , 7 0} \pm 17,59$ & $\mathbf{6 , 3 0 \pm 4 , 6 5}$ & $\mathbf{5 , 0 7} \pm 1,19$ & $\mathbf{4 , 9 0} \pm 1,30$ & $\mathbf{5 , 4 9} \pm 0,75$ \\
\hline $\begin{array}{l}\text { 17. (22 ülés) } \\
29 \text { éves nô } \\
\end{array}$ & $\mathbf{7 8 , 1 8} \pm 18,49$ & $\mathbf{3 , 7 7 \pm 1 , 0 2}$ & $\mathbf{4 , 8 0} \pm 1,04$ & $\mathbf{4 , 2 9} \pm 1,24$ & $\mathbf{3 , 5 6} \pm 1,00$ \\
\hline $\begin{array}{l}\text { 18. (22 ülés) } \\
42 \text { éves nô }\end{array}$ & $\mathbf{4 9 , 0 0} \pm 13,33$ & $\mathbf{3 , 1 0} \pm 1,54$ & $\mathbf{3 , 0 7} \pm 1,17$ & $\mathbf{2 , 5 7} \pm 1,24$ & $\mathbf{2 , 2 7} \pm 0,64$ \\
\hline $\begin{array}{l}\text { 19. (10 ülés) } \\
32 \text { éves nô }\end{array}$ & $\mathbf{5 7 , 3 0} \pm 12,08$ & $\mathbf{3 , 0 0} \pm 0,00$ & $4,14 \pm 1,12$ & $\mathbf{4 , 1 7} \pm 1,04$ & $\mathbf{1 , 4 5} \pm 0,70$ \\
\hline $\begin{array}{l}\text { 20. (15 ülés) } \\
29 \text { éves nố }\end{array}$ & $\mathbf{7 3 , 5 0} \pm 10,81$ & $\mathbf{6 , 1 3} \pm 2,06$ & $4,11 \pm 1,00$ & $\mathbf{3 , 8 9} \pm 1,05$ & $3,72 \pm 0,55$ \\
\hline $\begin{array}{l}\text { Összminta } \\
(N=384)\end{array}$ & $\mathbf{5 5 , 3 5} \pm 23,15$ & $\mathbf{4 , 4 9} \pm 2,43$ & $\mathbf{3 , 1 9} \pm 1,35$ & $\mathbf{2 , 9 5} \pm 1,51$ & $\mathbf{2 , 7 2} \pm 1,39$ \\
\hline
\end{tabular}

Megjegyzés: 384 hipnózisülés alapján, a csak egy, illetve két ülést tartó hipnotizôr adata itt nem szerepel. 


\section{MEGBESZÉLÉS ÉS KITEKINTÉS}

Vizsgálatunk fớ célja az volt, hogy empirikus adatokkal igazoljuk az általunk bevezetett hipnotizôri Archaikus Bevonódási Skála alkalmazhatóságát. Eredményeink igazolják, hogy hipnotizőrökben is kialakul az alanyok áttételi viszonyulásához hasonló mértékú és az ABS(H) skálával megbízhatóan mérhetô archaikus bevonódás. Bár az alanyok ABS+ pontszámának átlaga szignifikánsan magasabb a hipnotizôrökénél, a hatásméret alapján ez nem tekinthetô nagy különbségnek. Az ABS- pontszámban pedig nincs szignifikáns különbség az alanyok és hipnotizôrök között. Az adatok terjedelmének hasonlósága rámutat arra, hogy a hipnotizőrök bevonódásában nagyfokú változatosság van. Úgy tûnik, még a kísérleti helyzet is lehetôséget nyújt - hipnotizôrök esetében is - a skála által mérhetô szinte maximális bevonódás megjelenésére. Ugyanakkor az alanyok bevonódásában a hipnotizôr személye szerint nem volt jelentôs különbség. Ez azt sugallja, hogy a hipnotizôrök - akárcsak a terapeuták más-más klienssel végzett pszichoterápiás munkában - még a standard laboratóriumi helyzetben is eltérô intenzitású és színezetû viszontáttételi érzelmeket élhetnek át (miközben az alanyok érzelmi bevonódása különbözô hipnotizôrök iránt is hasonló erôsségú).

Vizsgáltuk az $\mathrm{ABS}(\mathrm{H})$ faktorszerkezetét is. Korábbi, kisebb elemszámmal végzett elôzetes vizsgálatunk (Bányai és Tauszik, 2009) négy faktort azonosított: Kötôdés és pozitív kapcsolat, Gondoskodás és töródésigény, Félelem a negatív megitéléstól, valamint Kontrolligény. Azonban a jelenlegi 387 hipnózisülés alapján végzett elemzés - az alanyokhoz hasonlóan - a hipnotizóröknél is három faktort azonosított, az elôvizsgálat két faktorának összeolvadásával: Kötődés és pozitív kapcsolat, Gondoskodás és törôdésigény, valamint Kontrolligény és félelem a negatí megitéléstól.

A hipnotizóröknél a faktorok összetétele és emiatt elnevezése is kissé különbözik az alanyokétól. Míg az alanyoknál a kilenctételes Csodálat és kötôdés faktor a leghangsúlyosabb, addig a hipnotizőröknél az ennek tükörképeként felfogható Kötôdés és pozitív kapcsolat faktor mindössze öt tételbôl tevôdik össze. Az alanyok Függôségigény faktora csupán négy tételt tartalmaz. Az ezeknek megfeleltethetô tételek a hipnotizőröknél fele-fele arányban a Gondoskodás és törôdésigény, illetve a Kontrolligény és félelem a negatív megítéléstôl faktorba kerültek.

A hipnotizôrök esetében a Kontrolligény és félelem a negatív megítéléstól faktor tartalmazza a legtöbb (nyolc) tételt. Ebból öt tétel teljesen megfeleltethetô az ABS(A) Félelem a negatív megítéléstôl faktor tételeinek. Ugyanide rendezôdik az alanyok Függôségigény faktorából ide átkerülő - korábban már említett - két tétel, melyeket egy olyan tétel egészít ki, amely az alanyoknál a Csodálat és kötôdés faktorba tartozik.

Ezek a különbségek jól értelmezhetôk a vizsgálatainkban részt vevô alany- és hipnotizôrpopulációk jellegzetességei alapján. A hipnózishelyzet mindkét interakciós partnerben aktiválhatta a korai szülő-gyerek kapcsolat érzelmi viszonyulási mintáit. Alanyaink egészséges, önként jelentkezô személyek voltak, a hipnotizôrök pedig a Magyar Hipnózis Egyesület többségében terápiás gyakorlatot is folytató tagjaiból tevôdtek össze. Természetes, hogy az egészséges személyekben is kialakul a függóségigény hipnózishelyzetben, hiszen feltehetôen azért jelentkeztek a vizsgálatba, mert át akarták élni, hogy újszerú élményeket tapasztalnak meg a hipnotizôr szuggesztióinak hatására (mint ahogy egy kíváncsi kisgyerek is szülei jelenlétében explorálhatja leginkább 
az új környezetet). Ezt támasztja alá az is, hogy az alanyok a részvételért nem részesültek fizetségben. Egészséges felnôttekként valószínúleg nem vágytak különösképpen gondoskodásra. A hipnotizôrök terápiás, segítô attitúdje viszont úgy túnik, ebben a kísérleti helyzetben is megnyilvánult. Munkacsoportunk más vizsgálataiban (1. Kasos és mtsai pp. 79-93., illetve Varga tanulmányát, pp. 95-112., a jelen tematikus számban) megfigyeltük, hogy a hipnotizôrben bekövetkezó pszichoendokrin változások intenzitása összefüggött az alanyok által felidézett bizonyos szülôi nevelési stílusokkal, ami arra utal, hogy a hipnotizór tudattalanul reagálhat az alany által a hipnózisba „hozott” szülôi kötôdési modellekre.

Az alanyok szuggesztiókra adott aktuális válaszkészsége és az archaikus bevonódás összefüggéseinek mintázata mintha arra utalna, hogy az alanyokban annál erôsebb a pozitív archaikus bevonódás, minél inkább reagálnak viselkedéses szinten is a hipnotikus szuggesztiókra. Ez a hipnotizörökben is hasonló mértékú gondoskodást és törôdést mobilizál. Bár a korrelációkból nem vonhatunk le ok-okozati kapcsolatra vonatkozó következtetéseket, a késôbbiekben a viselkedéses válaszkészség mediáló szerepét is indokolt lenne vizsgálat tárgyává tenni.

A jelen vizsgálat hipnotizôreinek nemi, életkorbeli és hipnábilitás szerinti egyenlôtlen eloszlása nem tette lehetôvé, hogy szisztematikusan vizsgáljuk archaikus bevonódásuk összefüggéseit ezekkel a tényezôkkel. A jövôben ezeknek a tényezóknek a hatását is érdemes vizsgálni.

Korábbi elemzésünkben a hipnózis stílusa és az archaikus bevonódás között is kapcsolatot találtunk. A jelen vizsgálat mintáján a stílusok megítélése eddig még nem történt meg. A hipnózis gyakorlati terápiás felhasználása szempontjából különösen fontosnak túnik a hipnózis stílusa és az archaikus bevonódás közti összefüggés elemzése. A jelen vizsgálat azt mutatja, hogy míg az alanyok a hipnotizốr személyétốl függetlenül hasonló mértékú archaikus bevonódást élnek át, addig az egyes hipnotizôrök által átélt archaikus bevonódás erôssége jelentôs különbségeket mutat. Mintánkban szerepel olyan hipnotizôr, aki minden ABS(H)-skálán szinte a minimális pontszámot adta azaz a kérdôíves adatok szerint érzelmileg nem vonódott be az általa végzett kísérleti hipnózisokba -, míg más hipnotizőrök erôsebb pozitív vagy negatív érzelmeket fejeztek ki ilyen körülmények között is. Feltételezésünk szerint ez a különbség a hipnózis stílusával függhet össze. Ennek igazolására a hipnotizôrök archaikus bevonódásával kapcsolatos jövôbeli vizsgálatainkat a viselkedéses mutatókon kívül az élménymutatókra (lásd a jelen tematikus számban Józsa és mtsai, pp. 27-43., illetve Varga tanulmányait, pp. 95-112.), valamint a hipnotizôrök saját neveltetésével, szüleivel kapcsolatos élményeire (lásd a jelen tematikus számban Költô és mtsai tanulmányát, pp. 63-78.) is ki kívánjuk terjeszteni. 


\section{MELLÉKLET: AZ ALANYOKNÁL ALKALMAZOTT ABS KÉRDŌÍV**}

Név:

Dátum:

Az alábbiakban néhány megállapítást talál. Olvassa el figyelmesen valamennyit, és mindegyikre vonatkozóan karikázza be azt a számot, amelyik leginkább megfelel hipnózis alatti érzéseinek. A növekvô értékek fokozatos átmenetet jelentenek a két szélsố érték között. Nincsenek helyes vagy helytelen válaszok, ne gondolkozzon túl sokat, hanem a hipnózisbeli érzéseit legjobban kifejezô számot jelölje meg.

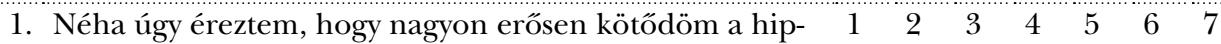
notizôrhöz. Olyan érzés volt ez, amit általában csak a szüleim, egyes tanáraim és a legjobb barátaim iránt érzek.

2. Nem is tudom miért, de valahogy tényleg nagyon a hip- $\begin{array}{llllllllllll}1 & 2 & 3 & 4 & 5 & 6 & 7\end{array}$ notizốr kedvében akartam járni.

3. Ưgy tûnt, hogy a hipnotizốr minden szava és tette vala- $\begin{array}{llllllllllll} & 1 & 2 & 3 & 4 & 5 & 6 & 7\end{array}$ hogy befolyásolta az érzéseimet.

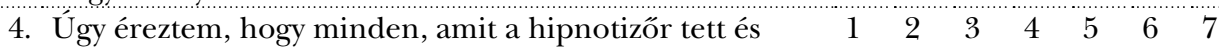
mondott, mélyen érint.

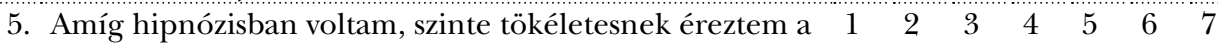
hipnotizőrt.

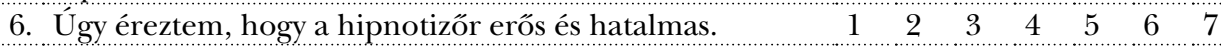

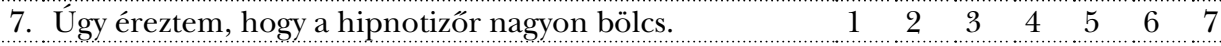

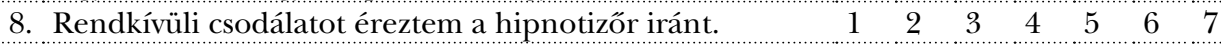

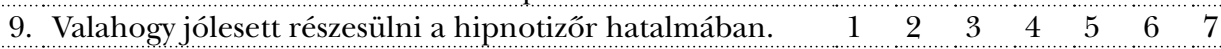

10. Igazán akartam, hogy a hipnotizốr úgy találja, hogy jól $\begin{array}{lllllllllll}1 & 2 & 3 & 4 & 5 & 6 & 7\end{array}$ csinálom a dolgokat.

11. Valahogy inkább szüleivel lévô gyermeknek éreztem ma- $\begin{array}{llllllllll}1 & 2 & 3 & 4 & 5 & 6 & 7\end{array}$ gam, mintsem egy hipnotizốrrel lévô felnôttnek.

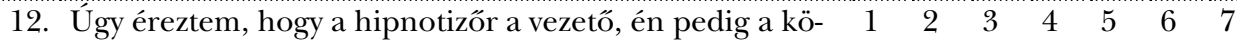
vetôje vagyok.

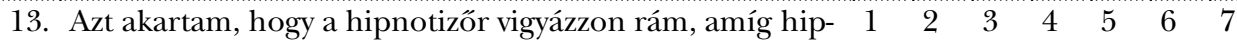
nózisban vagyok.

14. Azt akartam, hogy a hipnotizór mondja meg, mit tegyek. $\quad 1 \quad 2 \quad \begin{array}{llllll}3 & 3 & 4 & 5 & 6 & 7\end{array}$

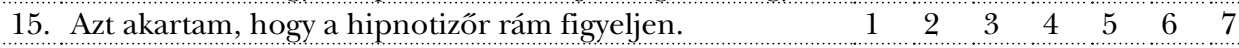

16. Amikor nem tudtam megtenni, amit a hipnotizốr mon- $\begin{array}{llllllllll}1 & 2 & 3 & 4 & 5 & 6 & 7\end{array}$ dott, lelkifurdalásom támadt.

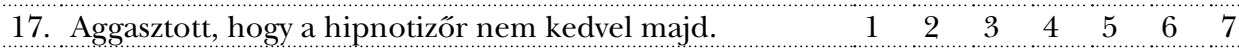

18. El akartam kerülni, hogy a hipnotizốr csalódjon ben- $\begin{array}{llllllllllll}1 & 1 & 2 & 3 & 4 & 5 & 6 & 7\end{array}$ nem.

19. El akartam kerülni, hogy a hipnotizôr megharagudjon $\begin{array}{lllllllll}1 & 2 & 3 & 4 & 5 & 6 & 7\end{array}$ rám.

* A kérdôív elsố tizenkilenc, pozitív tétele magyarul már megjelent (Bányai és mtsai, 2001, 335-336). Köszönetünket fejezzük ki az ELTE Eötvös Kiadónak, hogy engedélyezte ezen tételek ismételt megjelenését. 
20. Volt, amikor taszított a hipnotizór. Olyan érzés volt ez, $\begin{array}{lllllllllllllll} & 1 & 2 & 3 & 4 & 5 & 6 & 7\end{array}$ amit általában csak a szüleivel, egyes tanáraival és barátaival kapcsolatban érez az ember.

21. Nem is tudom miért, de valahogy néha kifejezetten a $\begin{array}{lllllllllll}1 & 2 & 3 & 4 & 5 & 6 & 7\end{array}$ hipnotizốr ellenére akartam tenni.

22. Valahogy rosszul esett, hogy szinte eltörpültem a hipno- $\begin{array}{llllllllllll}1 & 2 & 3 & 4 & 5 & 6 & 7\end{array}$ tizôr mellett.

\section{MELLÉKLET: A HIPNOTIZŐRÖKNÉL ALKALMAZOTT ABS KÉRDŐÍV}

Név:

(K.sz.:

) Dátum:

Az alábbiakban néhány megállapítást talál. Olvassa el figyelmesen valamennyit, és mindegyikre vonatkozóan karikázza be azt a számot, amelyik leginkább megfelel hipnózis alatti érzéseinek. A növekvő értékek fokozatos átmenetet jelentenek a két szélsô érték között. Nincsenek helyes vagy helytelen válaszok, ne gondolkozzon túl sokat, hanem a hipnózisbeli érzéseit legjobban kifejezô számot jelölje meg.

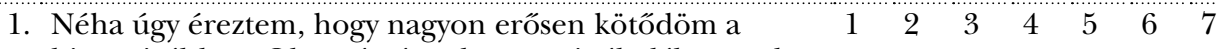
hipnotizálthoz. Olyan érzés volt ez, amit általában csak a gyerekei, egyes betegei/tanítványai és a legjobb barátai iránt érez az ember.

2. Nem is tudom miért, de valahogy tényleg nagyon a $\quad \begin{array}{lllllllllllll} & 1 & 2 & 3 & 4 & 5 & 6 & 7\end{array}$ hipnotizált kedvében akartam járni.

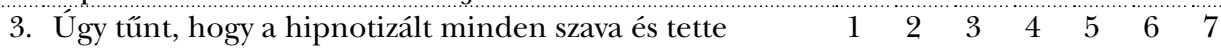
valahogy befolyásolta az érzéseimet.

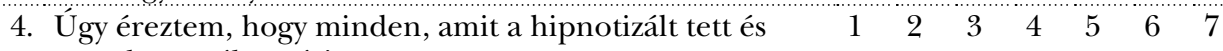
mondott, mélyen érint.

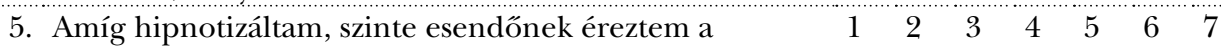
hipnotizáltat.

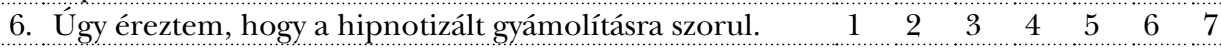

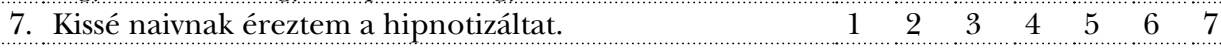

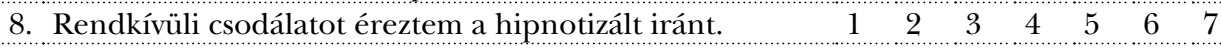

9. Valahogy jólesett a hipnotizáltat a hatalmamban $\quad \begin{array}{llllllllllllll}1 & 2 & 3 & 4 & 5 & 6 & 7\end{array}$ részesíteni.

10. Arra törekedtem, hogy a hipnotizált meg akarjon felelni $1 \begin{array}{lllllllllll}1 & 2 & 3 & 4 & 5 & 6 & 7\end{array}$ nekem.

11. Valahogy inkább gyermekével lévố szülónek éreztem $\begin{array}{lllllllllllll}1 & 2 & 3 & 4 & 5 & 6 & 7\end{array}$ magam, mintsem egy felnôttel lévố hipnotizôrnek.

12. Úgy éreztem, hogy én vagyok a vezetố, a hipnotizált $\begin{array}{lllllllllllllll}1 & 2 & 3 & 4 & 5 & 6 & 7\end{array}$ pedig követ engem.

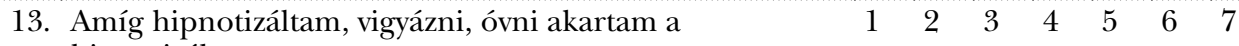
hipnotizáltat.

14. Én akartam meghatározni, hogy a hipnotizált mit tegyen. $110 \begin{array}{lllllllll} & 2 & 3 & 4 & 5 & 6 & 7\end{array}$

15. Azt akartam, hogy a hipnotizált rám figyeljen. $\quad \begin{array}{lllllllllll} & 1 & 2 & 3 & 4 & 5 & 6 & 7\end{array}$ 
16. Amikor olyat kértem, amit a hipnotizált nem tudott $\quad \begin{array}{lllllllllllll}1 & 2 & 3 & 4 & 5 & 6 & 7\end{array}$ megtenni, rossz érzésem támadt.

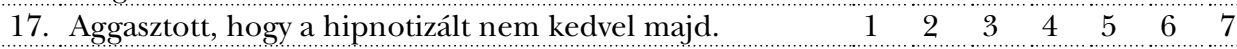

18. El akartam kerülni, hogy a hipnotizált csalódjon $\quad \begin{array}{lllllllllllllllllll}1 & 2 & 3 & 4 & 5 & 6 & 7\end{array}$ bennem.

19. El akartam kerülni, hogy a hipnotizált megharagudjon $\begin{array}{rllllllll}1 & 2 & 3 & 4 & 5 & 6 & 7\end{array}$ rám.

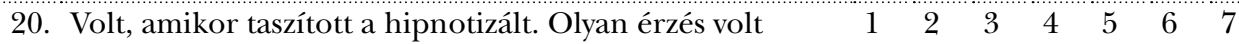
ez, amit általában csak a gyerekeivel, egyes betegeivel/ tanítványaival és barátaival kapcsolatban érez az ember.

21. Nem is tudom miért, de valahogy néha kifejezetten a $\begin{array}{llllllllllll}1 & 2 & 3 & 4 & 5 & 6 & 7\end{array}$ hipnotizált ellenére akartam tenni.

22. Zavart, hogy a hipnotizált rám szorul. $\quad \begin{array}{llllllllll}1 & 2 & 3 & 4 & 5 & 6 & 7\end{array}$

\section{IRODALOM}

Bachner-Melman, R., \& Lichtenberg, P. (2001). Freud's relevance to hypnosis: A reevaluation. American Journal of Clinical Hypnosis, 44(1), 37-50.

Bányai É. (2008). A hipnózis szociál-pszichobiológiai modellje. In Bányai É., \& Benczúr L. (szerk.), A hipnózis és a hipnoterápia alapjai (pp. 379-445). Budapest, Hungary: ELTE Eötvös Kiadó.

Bányai, É., Gốsi-Greguss, A. C., Vágó, P., Varga, K., \& Horváth, R. (1990). Interactional approach to the understanding of hypnosis: Theoretical background and main findings. In R. Van Dyck, P. Spinhoven, A. J. W. Van der Does, Y. R. Van Rood, \& W. De Moor (Eds), Hypnosis: Current theory, research and practice (pp. 53-69). Amsterdam, The Netherlands: Free University Press.

Bányai, É., Mészáros, I., Greguss, A., Gerber, A., \& Csókay, L. (1974). Stanford Hipnotikus Szuszceptibilitási Skála C változata. Kézirat. Budapest: Eötvös Loránd Tudományegyetem Természettudományi Kar.

Bányai É., \& Tauszik K. (2009). A hipnózis kapcsolati dimenziója: kölcsönös archaikus bevonódás. Elôadás az Illyés Sándor Emléknapokon. Budapest, 2009. március 18-20.

Bányai É., Varga K., \& Gôsiné Greguss A. C. (2001). Szuggesztív egyéniségek: archaikus bevonódás tanárok és hipnotizórök hatására. In Pléh Cs., László J., \& Oláh A. (szerk.), Tanulás, kezdeményezés, alkotás: Barkóczi Ilona 75. születésnapjára (pp. 313-336). Budapest: ELTE Eötvös Kiadó.

Bernheim, H. (1884). De la suggestion dans l'état hypnotique et dans l'état de veille. Paris: Doin.

Brown, D. P., \& Fromm, E. (1986). Hypnotherapy and Hypnoanalysis. Hillsdale, USA: Lawrence Erlbaum Associates.

Cabré, L. J. M. (1999). Ferenczi Sándor hozzájárulása a viszontáttétel fogalmához. Thalassa, $10(1), 3-22$.

Eisen, M. R. (1993). Psychoanalytic and psychodynamic models pf hypnoanalysis. In J. W. Rhue, S. J. Lynn, \& I. Kirsch (Eds), Handbook of Clinical Hypnosis (pp. 123-149). Washington, D. C., USA: American Psychological Association.

Ellenberger, H. F. (1970). The discovery of the unconscious. New York, NY: Basic Books.

Ferenczi, S. (1909/2002). Introjection and transference. In J. Dupont (Ed.), First Contributions to Psycho-Analysis: Sándor Ferenczi (pp. 35-93). London, England: H. Karnac Books Ltd.

Freud, S. (1921/1995). Tömegpszichológia és én-analízis. In Sigmund Freud Múvei V. Tömegpszichológia. Társadalomlélektani írások (pp. 185-248). Budapest: Cserépfalvi Könyvkiadó. 
Janet, P. (1897). L'Influence somnambulique et le besoin de direction. Revue Philosophique de la France et de l'étranger, 43, 113-143.

Józsa E. (2011). A raport fogalma és szerepe az orvosi kommunikációban. In Varga K. (szerk.), A szavakon túl: Kommunikáció és szuggesztió az orvosi gyakorlatban (pp. 78-99). Budapest: Medicina Könyvkiadó.

Józsa E. (2012). Diádikus interakciós élménymintázatok. Doktori (PhD) értekezés. Budapest: Eötvös Loránd Tudományegyetem Pszichológiai Doktori Iskola.

Kernberg, O. (1965). Notes on Countertransference. Journal of the American Psychoanalytic Association, 13(1), 38-56.

Levitt, E. E., Baker, E. L., \& Fish, R. C. (1990). Some Conditions of Compliance and Resistance among Hypnotic Subjects. American Journal of Clinical Hypnosis, 32(4), 225-236.

Mészáros I., Bányai É., Greguss A., Gerber A., \& Csókay L. (1973). Stanford Hipnotikus Szuszceptibilitási Skála A és B változata. Kézirat. Budapest: Eötvös Loránd Tudományegyetem Természettudományi Kar.

Nash, M. R., \& Spinler, D. (1989). Hypnosis and transference: A measure of archaic involvement. International Journal of Clinical and Experimental Hypnosis, 37(2), 129-144.

Sheehan, P. W., \& Dolby, R. M. (1979). Motivated involvement in hypnosis: The illustration of clinical rapport through hypnotic dreams. Journal of Abnormal Psychology, 88(5), 573-583.

Shor, R. E. (1962). Three dimensions of hypnotic depth. International Journal of Clinical and Experimental Hypnosis, 10(1), 23-38.

Shor, R. E. (1979). A phenomenological method for the measurement of variables important to an understanding of the nature of hypnosis. In E. Fromm, \& R. E. Shor (Eds), Hypnosis: Developments in research and new perspectives (2nd ed., pp. 105-135). New York, USA: Aldine.

Varga K. (2017). A hipnotikus interakció fenomenológiája. Budapest: Medicina Könyvkiadó.

Varga, K., Bányai, É. I., \& Gôsi-Greguss, A. C. (1994). Parallel application of the experiential analysis technique with subject and hypnotist: A new possibility for measuring interactional synchrony. International Journal of Clinical and Experimental Hypnosis, 42(2), 130-139.

Weitzenhoffer, A. M., \& Hilgard, E. R. (1959). Stanford Hypnotic Susceptibility Scale, Forms A and B. Palo Alto, CA: Consulting Psychologists Press.

Weitzenhoffer, A. M., \& Hilgard, E. R. (1962). Stanford Hypnotic Susceptibility Scale, Form C. Palo Alto, CA: Consulting Psychologists Press.

White, R. W. (1941). A preface to the theory of hypnotism. Journal of Abnormal and Social Psychology, 36(4), 477-505. 


\title{
INVESTIGATING THE HYPNOTISTS’ ARCHAIC INVOLVEMENT
}

\author{
BÁNYAI, ÉVA - JÓZSA, EMESE - KÖLTŐ, ANDRÁS
}

Background and aims: The emotional (archaic) involvement of the hypnotic subjects can be investigated with the standardised Archaic Involvement Measure, $\operatorname{AIM}(S)$. The interactional approach of hypnosis, however, requires that the countertransference-like experiences are measured in the hypnotists as well. Our study introduces the 22-item hypnotist version of the Archaic Involvement Measure - AIM $(H)$ - developed in our laboratory for this aim and investigates the reliability and the factor structure of the questionnaire. Method: 22 hypnotists and their 387 subjects filled in the AIM after experimental hypnosis sessions. We calculated descriptive statistiscs, compared the intensity and the individual differences of archaic involvement of hypnotists and their subjects, and performed exploratory factor analysis on AIM $(H)$ items.

Results: The AIM $(H)$ items are organised in three factors: Attachment and positive relationship; Concern and need for caring; Need for control and fear of negative appraisal. The AIM $(H)$ is equally reliable as the version of AIM for subjects. Archaic involvement of hypnotists and subjects did not differ significantly or the difference has a low effect size. At the same time there were significant individual differences in archaic involvement among hypnotists.

Conclusion: The AIM $(H)$ is a reliable tool for measuring the countertransference-like experiences of hypnotists in experimental settings. Our results suggest that while subjects experience similar intensity of archaic involvements across interactions with different hypnotists, the emotional involvement of the hypnotists can be remarkably different across laboratory hypnosis sessions the hypnotist conducts with different subjects. This observation can deepen our understanding of the hypnotherapeutic relationship.

Keywords: hypnosis, archaic involvement, transference, counter-transference, interactional approach

A cikk a Creative Commons Attribution 4.0 International License (https:// creativecommons.org/licenses/by/4.0) feltételei szerint publikált Open Access közlemény, melynek szellemében a cikk bármilyen médiumban szabadon felhasználható, megosztható és újraközölhetô, feltéve, hogy az eredeti szerzô és a közlés helye, illetve a CC License linkje és az esetlegesen végrehajtott módosítások feltüntetésre kerülnek. (SID_1) 